\title{
THE STATUS OF LEATHER SUPPLY CHAIN IN EGYPT: AN EXPLORATORY STUDY FOR THE INNOLEA PROJECT
}

\author{
SANDRA SAMY GEORGE HADDAD \\ College of International Transport and Logistics, Arab Academy for Science, Technology and \\ Maritime Transport, sandra_hdd@yahoo.com
}

\begin{abstract}
Egypt has a traditional wealth in manufacture and use of leather and leather products as demonstrated on the walls of the tombs of pharaonic civilization. Nowadays the status of leather supply chain in Egypt has deteriorated and only account for a minor percentage of the Egyptian GDP. The INNOLEA (Erasmus+) project aims at developing and enhancing the leather supply chain through the establishment of leather innovation centers in Egypt and Jordan. The project also aims to create a link between university research activities and the leather sector which shall foster innovation and lead to manufacturing of high quality products. In this regard four focus group discussions have been organized with a total of nineteen participants (4-5 in each group) from different leather sector stakeholders (industry and academia). The outcomes of this research emphasized a number of steps to be undertaken to ensure a bright future the Egyptian leather supply chain with its main phases, tanning and leather products manufacturing. The industry has to undergo major technological advancements, produced leather products have to comply with the international norms and standards, government should increase its intervention and monitoring of this industry and support it stakeholders and labor professional skills and training have to be giving more emphasis and get developed.
\end{abstract}

Keywords: leather, leather products, quality, supply chain, Egypt, innovation center

\section{INTRODUCTION}

Egypt is sitting at its strategic location in the heart of the old world, at the North East of Africa with an area slightly over one million square kilometers (CIA World Factbook, 2018). Egypt emerged as one of the world's first nation states in the tenth millennium BC. and is considered a cradle of civilization. Ancient Egypt saw some of the earliest developments of writing, agriculture, urbanization, organized religion and central government (AFSTA Congress, 2018). Egyptian history has a traditional wealth in manufacture and use of leather and leather products as demonstrated on the walls of the tombs of pharaonic civilization. A statue displayed in the Egyptian Museum in Cairo of King Pepi II (2235-2141 B.C) shows the king holding his leather back bag. It is the earliest sign in the history of humanity of leather products (Elnaggar et al., 2017).

According to a 2017 study, the Egyptian economy sectoral analysis showed that $55.7 \%$ of the Egyptian GDP is generated by the service sector, followed by the industrial sector with a $33.1 \%$ of the GDP where the leather industry's contribution to the industrial sector added value is limited to the level of $0.4 \%$ (CAPMAS, 2017). This presents an opportunity for development of the leather sector.

This research is part of the "Innovation for the Leather Industry in Jordan and Egypt (INNOLEA)"; an Erasmus+ project which aims to fill the current gap in the area of specialized services for the leather sector with the establishment of four leather centers in local universities in Jordan and Egypt. This paper focuses on presenting the status of the Egyptian leather supply chain and exploring the current situation of the leather industry. The paper highlights the areas of developments and opportunities for the leather supply chain with a special focus on assessing the sector's capacities and identifying training needs. The results of this research shall be used as a corner stone for classifying the leather supply chain players status and needs and designing the prospective training and testing centers' action plan. 


\section{LITERATURE REVIEW}

The Egyptian leather industry has witnessed instability in recent years. The total number of leather facilities in Egypt is more than 17,000 but about 5,000 factories have been closed and more than 150,000 workers have been laid off due to several reasons, foremost of which is the stream of imports (CAPMAS, 2016). The Ministry of Commerce and Industry issued a decree to protect the Egyptian leather industry, which included reviewing the Egyptian standards for imported leather products and introduced a customs tariff on imported leather products. The government is also in the process of reconsidering the rules governing the control of the production requirements for factories producing natural and industrial leathers (IMC, 2017).

In response to industrial and environmental needs, the Egyptian government made the decision to transfer the tanning industry, presently situated in Old Cairo, in the heart of the capital, to the industrial area near of Badr City (Al-Robikki area), which is situated approximately 45 kilometers from the capital (Egypt Today, 2016). This decision by the government is of particular importance, on the one hand it was a choice imposed by the limits of environmental acceptability of urban industrial development, and on the other, it expressed a desire to take the opportunity to support and strengthen the Egyptian tanning industry by helping it to become part of an industrial economy (Knecht and Zaki, 2017).

The Egyptian leather supply chain consist of the suppliers of animal hides and skins to the tanneries that convert them in into leather which is then exported or converted by leather products manufacturers into footwear, leather goods, garments, bags and sports goods. The manufactures either export or sell the products to retail shops to be in turn sold to final consumers. The substantial part of the industriy and business in Egypt remains with the tanneries and the manufacturing companies (FAO, 2016).

At present the Egyptian small and medium scale tanneries, that do not have the capital to move the Al-Robikki new industrial zone, are not in a bright situation. Moreover, only a few are industrially organized and able to offer a product suitable for the international market. This is particularly true for about 320 tanneries in Old Cairo, which are predominantly artisan workshops, with insufficient and often obsolete machinery. Their production appears to lack a rational organization, and the spaces they occupy are in buildings which are completely inadequate for running a modern production (Unido, 2016).

The tanneries in Egypt used a variety of animal skins and hides to extract leather such as bovine animals, sheep, lambs, and goats. Egyptian wealth of cow hides, sheep and goat skins are characterized by high quality fibrous structure as well as unique grain patternwell known at the overseas markets. The animal wealth of the country is estimated at $8 \mathrm{M}$. bovines (cow/buffaloes), $6 \mathrm{M}$. sheep and $5 \mathrm{M}$. Goats; which follows in general a smallscale pattern of animal husbandry rather than large scale herds raising (FAO, 2016).

Slaughter and flaying are undertaken at authorized slaughter houses as well as informal village private slaughters. Thus, during the informal slaughter practices a part of country's wealth of hides and skins is jeopardized and subject to serious post- mortem defects. This leads to eventual marked reduction in the raw material value and sequent lower grade/value of manufactured leather whether semi- processed, crust or finished (FAO, 2016).

On the manufacturing side, the leather products in Egypt are classified into three main subsectors: footwear, leather goods and leather garments. The biggest sector is footwear representing 85 percent of the Egyptian industrial activities among the leather-based industries but still facing severe competition with imported products (CAPMAS, 2015; FAO, 2016). 
Therefore, based on the secondary data collected the leather sector in Egypt carries a high potential but shows a gap with the international standards. That was the main driver of the INNOLEA project which is directed towards supporting the leather supply chain development through the establishment of leather centers providing totally new services such as; quality testing; certification of products; training; informative seminars on fashion trends, organization of production, funding opportunities etc. The centers shall be established at the Arab Academy for Science, Technology and Maritime Transport (AASTMT) and South Valley university (SVU). The project also aims to create a link between university research activities and the leather sector which shall enhance innovation and manufacturing.

\section{RESEARCH METHODOLOGY}

Insufficient reliable statistics, lack of extensive previous studies and records on the leather industry status, tannery, production, fabrication and exports in Egypt made it difficult to collect the necessary information. Thus, qualitative data gathering methods were vital in extracting in-depth information about the industry from the different leather supply chain stakeholder. In this regard four focus group discussions have been organized by the Egyptian partners in the INNOLEA project on the 28th of March in Cairo and the 24th of April 2018 in Alexandria. Total number of participants in the four focus groups is nineteen participants (4-5 in each group) from different leather sector stakeholders (industry and academia). Each focus group discussion took about 120 minutes. To ensure comparability between the focus groups, the same set of questions were asked to participants at each meeting. The questions were set to be compatible with the Egyptian market, reflecting an in-depth investigation of the current situation of the sector in Egypt.

It is worth mentioning that these national focus groups were the first of their kind relating academic staff to their counterparts' leather industrial experts in Egypt. The focus groups also included representatives from Egyptian Industrial Chamber as policymakers. The discussions were fruitful in identifying the problems and challenges facing this vital sector in Egypt, to determine its needs, and to recommend solutions to promote and enhance its performance to compete in the global market. They also focused on describing the status of the leather industry in Egypt, areas of collaboration between leather industry and academia, and recommendations to the government to help the leather industry sector in Egypt.

\section{DATA ANALYSIS AND INTERPRETATION}

After analyzing the outcomes of the focus groups' discussions, the status of the leather supply chain in the country was described, future of the industry was discussed, government policies were recommended and areas for collaboration with universities were explored.

\section{The Status of the Leather Supply Chain}

The Egyptian lather industry was characterized as random and governed by a weak legal framework. The supply chain of leather consists of small fragmented firms with limited ability to pump investment for growth. Meanwhile, the government plans to regulate and rationalize the industry through establishing a new leather industrial area called El Robbiki in Cairo. Nevertheless, huge infrastructure development is need in Alexandria too as tannery areas are older than Cairo. 
Moreover, the Egyptian leather industry is facing a major threat as the Chinese products are invading the Egyptian market. The size of the Egyptian markets attracts low cost foreign leather products especially from China and the Egyptian leather products do not stand strong in the face of this severe competition. The Chinese synthetic leather products are well designed with acceptable quality for a considerable market segment of Egyptians and offered at cheap prices. This decreases the opportunities of Egyptian leather products to compete. Consumers are shifting to synthesized leather due to the soaring up prices of natural leather as well as increase in the price of materials associated with the production process. The annual Egyptian imported footwear and belts exceed 100 Million pieces.

In addition, some of the produced leather products are of poor quality which provides limited chances to compete with foreign products or to export. Majority of tanneries export raw leather (crust, dry crust, wet blue "recently illegal") to China, India, Spain and Italy. Few exporters/producers export high quality competitive finished leather products. These factories export Egyptian leather to Romania, Turkey and China.

The leather supply chain with its two main phases (tanning and manufacturing leather products) lack integration. Both areas are also in continuous disputes.

The status of leather tanning: The status of leather tanning was discussed and described by the participants. There are over 300 registered tanneries in Egypt. 80\% of the high quality Egyptian semi-finished hides and skins (wet-blue and crust) are exported without added value, and the remaining low quality $20 \%$ are directed to the local market. Tanneries view exporting leather as being more profitable than selling locally. Leather finished products are not up to standards of European countries, however, raw leather quality is very good, demanded, conforms to specifications of the importing countries and can compete abroad. Reaching the stage of crust and dry crust need minor valued added activities (lining, decreasing, wet blue, spraying, dry crust) which is not costly, materials used are not expensive and widely available. Tannery owners prefer workers that inherited the craft to higher education graduates as they prefer traditional methods. Waste and scrap are considered a threat to the environment that needs to be addressed.

Most workers in the industry especially tanneries are uneducated and with minor skills. Tanneries' owners are seeking improvements through the help of foreign technicians from Bangladesh and India. There is a great need for more training involving employees throughout the production process. The government is also giving more care for leather tanning than leather manufacturing.

As for the status of leather manufacturing: only a few producers operate at a large scale and follow international standards. The industry in general is not strong as producers are not engaged in mass production due to limited capital resources of the majority of companies operating in the industry. Most producers are mainly small enterprises and family businesses that have inherited the craft years ago. According to participants' information, there are over 17,000 workshops for leather products manufacturing in Egypt. Supply of local materials and tools is very limited. Meanwhile, leather manufacturing requires high quality accessories, manufacturing components and auxiliaries. Many supporting industries are not available or available at low quality in Egypt. Some of the parts that are needed to manufacture leather products are prohibited to be imported by laws.

\section{The Future of the Leather Industry in the Country}

Leather industry has a great potential in case of solving its problems, which cannot be achieved with government intervention to further regulate the industry. The internal as 
well as external markets are very promising. Europe is a wide market that proposes a large opportunity for Egyptian leather products because of the high-quality natural leather (but low processing quality). Processors believe that Europeans like to wear leather and value high quality leather. For the local market, it is easier to compete, as Egyptian consumer are not experienced with differences in quality of leather, thus, their expectations are not very high, and their perception of quality is lower than that of Europeans.

If slaughtering is regulated and done according to standards volumes of locally produced hides and skins can cover both the Egyptian market needs and the export activities of the finished leathers. Manufacturers see the potential to convert the exported "crust" leather, which presents $80 \%$ of the total produced skins, to fabricated items, and gain the added value by exporting these finished products in case production techniques get advanced and partly automated. Moreover, as leather represents $45-65 \%$ of the value of finished leather products, and the rest is in the form of accessories, auxiliaries and other components (fabric, zipper, etc.), this can be seen as an opportunity for supporting industries to be developed.

In addition to the technical improvements need, the logistics of the supply chain of leather have to be worked on in terms of the establishment of distribution centers for different types of leather to provide the manufacturers with their needs and to cover a wider geographical area. Also, other logistics activities such as professional purchasing, packaging an inventory management are vital for the future of the industry. Participants also emphasized their need for appropriate marketing strategies domestically and internationally to promote Egyptian leather products.

\section{The Needed Steps and Regulations from the Government to Help the Leather Industry in the Country}

The government should regulate the industry and put greater emphasis on the inspection of imported and exported leather and leather products. It should set higher penalties for those who violate laws and export raw leather. The formation of an official body, to set specifications of leather and regulate the exportation and importation of leather and related material, is needed. The government official body shall also oversee quality control to ensure all needed specs are being followed at all stages of production.

Moreover, accredited labs should made available to test the quality of the raw leather and apply the international certifications alongside professional training for labors, technicians, engineers and designers. Financial support shall also be regulated and subsidies, for small and medium factories working on finished leather products, are required. The government should also work of establishing a supporting industry such as local chemical factories, accessories and auxiliaries to manufacture raw materials needed for the leather production, instead of importing them. Exports shall be encouraged by the government to participate in international exhibition by facilitating the procedures for the companies to get involved. and subsidizing participation

\section{Industry-Academia Collaboration}

The role of the universities is appreciated as a neutral party, as companies may be reluctant to incorporate in the training with the concern of disclosing its industrial secrets. There is a need for academic institutions to provide the market with qualified staff, advanced testing equipment and well trained technicians. The government shall encourage more universities to develop an educational program to teach and train students and 
workers. There are only a few educational institutions such as, he leather department in Helwan University which provide a high level of educational and vocational training.

Graduates from the academic institutes need to be trained on leather products fabrication and processing particularly in the stage of finished goods design, marketing and sales. The tannery owners highlighted a need for more trainings in the areas of deficiencies especially tanning which is the first stage in the leather supply chain. The current lack of knowledge at this stage affects the quality of the whole chain. Current standards and specifications can be developed by the academic institutions to match the fast progress in this industry. That may include specifications of both input materials and finished goods.

\section{CONCLUSION}

Analysis of the discussions indicated a level of deterioration in leather supply chain in Egypt and highlighted the root causes behind it. Areas of collaboration between the leather industry sector and the academia in Egypt have been identified and suggested to be partly fulfilled in the proposed leather innovation Centers that will be established through the INNOLEA project at AASTMT and SVU. In addition, suggestions and recommendations to the government have been identified in these focus group discussions.

To summarize the outcomes of this research and to ensure a bright future for this industry, the leather supply chain with its main phases, the tanning and leather finishing processes, have to undertake major technological advancements. Produced leather products have to comply with the international norms and standards. Government should increase its intervention and monitoring of this industry and support it stakeholders. Finally, labor professional skills and training have to be giving more emphasis and appropriately developed.

\section{REFERENCES}

AFSTA Congress (2018), African Seed Trade Association [online], available at: http://afsta.org/congress/blog/2017/09/28/afsta-congress-2018/

CAPMAS (2015), Egypt profile. Cairo: Central Agency for Public Mobilization and Statistics.

CAPMAS (2016), Egypt profile. Cairo: Central Agency for Public Mobilization and Statistics.

CAPMAS (2017), Egypt profile. Cairo: Central Agency for Public Mobilization and Statistics.

CIA (2015), The World Fact Book [online], available at: https://www.cia.gov/library/publications/the-worldfactbook/geos/eg.html.

Egypt Today (2016), Inside Old Cairo's Leather Tanneries, Cairo [online], available at: http://www.egypttoday.com/Article/10/3107/Inside-Old-Cairo-s-Leather-Tanneries.

Elnaggar et al. (2017), "The characterization of vegetable Tanning and coloring agents in ancient Egyptian leather from the collection of the metropolitan museum of art", Archaeometry, 59(1), 133-147.

FAO (2016), FAO in Egypt: Food and Agriculture Organization of the United Nations [online], available at: http://www.fao.org/countryprofiles/index/en/?iso3=EGY.

IMC (2017), Industry Modernization Centre [online], available at: http://www.imc-egypt.org/

Knecht and Zaki (2017), "Egypt pins export hopes on new leather production city", Reuters Egypt [online], available at: https://www.reuters.com/article/us-egypt-industry-leather-int/egypt-pins-export-hopes-onnew-leather-production-city-idUSKCN1B31P7.

UNIDO (2016), UNIDO activities in Egypt 2015-2016, United Nations Industrial Development Organization [online], available at: https://www.unido.org/sites/default/files/2016-04/UNIDO_Egy_20152016_web_0.pdf. 